\title{
FOREIGN DIRECT INVESTMENTS IN THE REGION OF WESTERN BALKANS
}

\author{
Prof. As. Dr. Blerta Dragusha ${ }^{1}$ \\ Prof. Ted Oelfke ${ }^{2}$ \\ M.sc. Ilirjana Gjergji ${ }^{3}$ \\ ${ }^{1}$ Faculty of Economy, University of Shkodra "Luigj Gurakuqi" \\ ${ }^{2}$ Sandhills Community College, North Carolina, USA
}

\begin{abstract}
Albania has adapted a liberal legal framework designed to create a favorable investment climate for foreign investors. It ranks among the countries with the highest level of foreign direct investments in the region after Serbia, but on the other hand has the lowest percentage of FDI-s in factories. According to data from the Regional Cooperation Council in 2016, only 10 percent of foreign investments in Albania were in factories, while in other countries of the region this number is higher. In FYROM, about 58 percent of FDI-s are concentrated in factories, in Serbia 35.2\% and in Bosnia and Hercegovina $27.1 \%$.

The six countries of the Western Balkans (Albania, Kosovo, Montenegro, FYROM, Serbia, Bosnia and Hercegovina) make up a market of no more than 20 million people, but their structure is much different because of their specific investment policies. In Montenegro, FDI-s are concentrated in the tourism sector, while in Albania the net inflows of FDI-s are related to major investment projects. In Serbia and FYROM investment inflows are in factories and mainly in the automotive industry, as well as in Bosnia and Hercegovina.

The Regional Coordination Council (RCC) has drafted a joint plan for attracting direct investments in the region. Infrastructure investments will be a pilot project to attract investments, but this will also be the basis for attracting future investments to other sectors of the economy, such as tourism and industry. In a detailed analysis of this issue, the RCC shows that some sectors of economy will be of interest to all the region economies, while some sectors may have less interest.

The paper focuses on six economies of Western Balkans: Albania, Bosnia and Herzegovina, FYROM, Kosovo, Montenegro, and Serbia, giving an overview of FDI in each country in the region and making a comparison between them.
\end{abstract}

Key words: Foreign Direct Investments, regional cooperation, country of origin, sectors of economy

\section{Introduction}

The importance of FDI-s is considered as a crucial priority for policymakers in the initial phases of transition process planned in the market economy, (Kukaj \& Ahmeti, 2016:289). (Imtiaz \& Bashir, 2017:291) claim that is noted that the improvement of economic openness by relieving barriers dhe obstacles for trade will attract more foreign investment in the region. 
One of the criteria that influences the FDI-s attraction is the tax cost. In this paper will be decribed six countries of Balkans: FYROM, Albania, Kosovo, Serbia, Bosnia and Herzegovina and Montenegro, as well as the opportunities and obstacles that these countries have for the FDI-s appeal.

\section{Description of the countries}

\subsection{FYROM (North Macedonia)}

FYROM's legal and regulatory framework is favourable to attract FDI-s. Moreover, the country adopted a new law in 2020 to create more favourable conditions for strategic investments. Investors benefit from a ten-year tax exemption personal and corporate income and free access to public services. Labour costs are low, but on the other hand there is often a shortage of skilled labour. The country has made significant efforts to harmonise its legal framework with the criteria, and practices of EU. Many challenges remain nonetheless, including corruption, lack of transparency, poor customer service, excessive bureaucracy, political interference in the judiciary, a lack of government capacity, communication difficulties and shortcomings in the rule of law and contract enforcement.

According to (ALTAX, 2018), from the ten countries of Balkans involved in the study (Albania, FYROM, Bulgaria, Serbia, Montenegro, Bosnia and Herzegovina, Greece, Romania, Kosovo and Croatia), FYROM is ranked as the country with the lowest tax costs in Balkans. This country has been following well-targeted strategies for the attraction of direct foreign investments. Its success has been in the appeal of large investitors in the automobiles production sector. FYROM is a member of WTO since 2003.

FYROM has signed three Multilateral Agreements of the Free Trade:

SAA (The Stabilization and Association Agreement) with the members of EU

$>$ EFTA (Switzerland, Norway, Iceland and Liechtenstein)

> CEFTA (FYROM, Albania, Moldavia, Serbia, Montenegro, Bosnia and Heregovina and Kosovo)

North Macedonia has also signed bilateral arrangements with Turkey and Ukraine. These agreements give to this country the opportunity to free access in a large market with more than 650 milion consumers.

Some of the weakest points of North Macedonia concerning FDI-s are:

$>\quad$ High structural unemployment and training deficit.

$>\quad$ Important size of informal economy.

$>\quad$ Inadequate transport infrastructure.

$>\quad$ Significant indebtedness of the private sector (93\% of GDP at the end of 2014).

$>\quad$ Conflicting political landscape.

$>\quad$ Tensions between the Slavic majority and the Albanian minority.

\subsection{Albania}

The focus for the future development of the Albanian economy remains the attraction of FDI-s with priority in sectors where the Albanian economy has large potential both in terms of natural resources and in the development of sectors that are not yet performing with their full capacity. Such sectors are: the renewable energy sector, the tourism sector, the agribusiness sector, the infrastructure sector and the services sector. 
Albania has set up reforms to icrease FDI-s. The country has adopted a tax reform that is advantageous to foreign investors and aims to reduce corruption and administrative difficulties which can be discouraging to investors. The long-winded procedures to obtain operating licences in the trade, construction and tourism industries have slowed down investment progress. A lack of transparency in public procurement and poor enforcement of contracts also hinder FDIs to Albania. In addition, investments continue to suffer from the lack of infrastructure and poorly defined property law.

Albania is a member of WTO since September 8,2000, and applies the WTO regime for the procedure of import licensing. According to the study of (ALTAX, 2018), Albania is ranked in the second place for the lowest tax costs. The crucial elements for this are the variety of fiscal policy and the continuous encouragement in orienting the investments toward the luxury tourism.

The Albanian government has approved the new law for Strategical Investments in the Republic of Albania. This law expressly predicts as "Strategical Investments": private investments, public invetments, and/or public-private investments in these economy's sectors: "Energy and Mining", "Transport, the infrastructure of electronic communication and urban waste", "Tourism", "Agriculture", "Technology and economic development area", and the areas with development priorities.

Some of the weakest points of this country concerning FDI-s are:

$>$ An ingrained informal economy with a considerable weight on GDP (56.7\% in 2019 according to the ILO, latest data available).

$>$ A relatively poor population with below-European standards, and low public investment in education of $3.6 \%$ of GDP (World Bank, latest data available).

$>$ An economy that is not very diversified and highly dependent on agriculture (18.5\% of GDP and 36.4\% of jobs in 2019 according to the World Bank, latest data available).

$>$ High risk of corruption and organised crime undermining the rule of law.

$>$ Fiscal and customs systems failing.

$>$ A lack of modern infrastructure.

$>$ Recurring energy shortages causing power cuts.

\subsection{Kosovo}

According to the World Bank, net FDI inflows represent 3.6\% of GDP in 2019. In 2019, the net flow of FDI into Kosovo was estimated at $\$ 292$ million. The stock of portfolio investments in 2019 totalled USD 2.05 billion, with equities worth USD 1.67 billion and debt securities worth USD 385 million. Real estate and leasing activities are the largest recipients of FDI, followed by financial services and energy. The food, IT, infrastructure and energy sectors are likely to attract more FDI-s in the future. The majority of FDI comes from Switzerland, Germany, Turkey, United Kingdom and Albania.

According to (ALTAX, 2018), Kosovo is the fourth country in the region regarding the lowest tax costs. One of the main advantages is that the dividend tax has a value of $0 \%$, and this constitutes a benefit for everyone who is considering investing in Kosovo. Another benefit is the total value of social and health contributions from the employer and employee, which are only $10 \%$. This is the lowest rate in the Balkans.

In June of 2013, the EU council gave the authorization to the European Commission to start the negotiations for the Stabilization and Association Agreement between Kosovo and EU, (Gashi\& Pugh, 2015:15). The Stabilization and Association Agreement (SAA) was signed in Strasburg, on October 27, 2015, between Kosovo and EU, (Palokaj \& Tuhina, 2016:8). This agreement became effective on April 1-st, 2016, Palokaj \& Tuhina, 2016:5).

Some of the weakest points of Kosovo concerning FDI-s are: 
$>$ Weaknesses in the legal system.

Kosovo has a good legal framework for protecting intellectual property rights, but enforcement remains weak, largely due to lack of resources.

$>$ Short electoral cycles and prolonged periods of caretaker governments in the country.

\subsection{Serbia}

According to the 2020 World Investment Report by UNCTAD, the inflow of FDI into Serbia rose to USD 4,3 billion in 2019, from USD 4,1 billion the previous year (+4.3\%) as a result of the country's improved business climate and equity capital growth. In 2019 the total stock of FDI stood at USD 44 billion. Serbia is the second-largest recipient of FDI among economies in transition after the Russian Federation. The European Union is the origin of $70 \%$ of investments in Serbia, followed by Russia, Switzerland and Hong Kong. According to FDI Intelligence, over the past five years, $56 \%$ of all greenfield FDI projects to Serbia have been in manufacturing.

As reported by (ALTAX, 2018), Serbia is classified in the sixth plae for the lowest tax costs in the region. Economic openness that Serbia is going through as part of membership process in EU and the agreement with IMF, the cheap and qualified labor force, and the free trade agreements with EU, Russia, Turkey, and the members of Free Trade Agreement of Central Europe constitute the essential elements that favor FDI-s in this country.

Furthermore, Serbia has improved the processes for business start ups, tax payment and contract implementation. The Ministry of Economy plans to continue offering incentives for foreign investors to further improve the business climate in the country. Another essential advantage is the geographical position that gives the opportunity to attract investors mainly in the road and railway transportation sector.

Some obstacles that may discourage foreign investitors in Serbia are:

$>$ Trade deficit and public debt level.

$>$ Lack of transport infrastructure and access to the sea is detrimental to this country.

$>$ High corruption level.

\subsection{Bosnia and Herzegovina}

According to UNCTAD's 2020 World Investment Report, FDI inflows amounted to USD 528 million in 2019, an increase from USD 473 million to the previous year. The total stock of FDI was estimated at USD 8,8 billion in 2019. According to preliminary data by the Bosnian Foreign Investment Promotion Agency (FIPA), FDI inflows in the period January-September 2019 amounted to EUR 440 million, marking a 29\% increase compared to the same period one year earlier. The largest investors in Bosnia and Herzegovina are Austria, Croatia, Serbia, Slovenia and the Netherlands (Central Bank of Bosnia and Herzegovina). The sectors that attract the most foreign investments in the country are manufacturing (34\% of total FDI stock), banking (25\%), telecommunications and trade (12\% each).

According to the studies conducted by (ALTAX, 2018), Bosnia and Herzegovina is ranked in the seventh place for the lowest tax costs in the region.

Bosnia and Herzegovina have signed or has ratified 42 investment agreements with these countries: Albania, Austria, Belgium, Belarus, China, Croatia, Czech Republic, Denmark, Egypt, Finland, France, Germany, Greece, Netherlands, Hungary, India, Luxembourg, Jordan, Kuwait, Lithuania, FYROM, Malaysia, Moldova, Montenegro, Pakistan, Portugal, Qatar, Romania, Serbia, Lybia, Slovakia, Slovenia, Spain, and Sweden. 
Bosnia and Herzegovina offer business opportunities for exporters and investors. This place is enriched in natural resources, providing potential chances in energy (hydro and thermal power plants), agriculture and tourism.

Some factors that have obstacled the development of FDI-s in this country are:

$>$ Labor cost in Bosnia and Herzegovina, which is one of the highest in this region, because of high rates of social contributions.

$>$ Political environment in Bosnia and Herzegovina, and the complicated structures that create large obstacles for the economic development and foreign direct investments.

$>$ To get registered in a business, 7 to 14 days are needed in average. But, in practice businesses report that it may get a longer time.

\subsection{Montengro}

According to the 2020 World Investment Report by UNCTAD, the inflow of FDI into Serbia rose to USD $4,3$ billion in 2019 , from USD 4,1 billion the previous year ( $+4.3 \%)$ as a result of the country's improved business climate and equity capital growth. In 2019 the total stock of FDI stood at USD 44 billion. Serbia is the second-largest recipient of FDI among economies in transition after the Russian Federation. The European Union is the origin of $70 \%$ of investments in Serbia, followed by Russia, Switzerland and Hong Kong. According to FDI Intelligence, over the past five years, 56\% of all greenfield FDI projects to Serbia have been in manufacturing. Data by the National Bank shows that the FDI influx increased by $14 \%$ y-o-y in the first four months of 2019.

As reported by (ALTAX, 2018), Montenegro is classified as the ninth country for the lowest tax costs. The adavantaged that this country possess are the geographical position, the flat tax of 9\%, qualified labor force and low salaries, and the usage of euro as the national currency. Also, is worth to mention that formalities to create a company last till four days.

Some obstacles that may discourage foreign investors in Serbia are:

Political instability.

$>$ The trade deficit and the level of public debt remain problematic for the country's economy.

$>$ The lack of transportation infrastructure and landlocked country.

$>$ High level of corruption.

$>$ Vulnerability of the exchange rate to price changes.

\section{Economic rankings}

Economies are ranked from 1-190 based on their ease to make business. A high ease means that the regulator environment is more favorable for the start and functioning of the local business.

In accordance with (Doing Business, 2020) for the six elected countries of this study, the following ranking is given: 
Figure 1- Ease of Doing Business Rank

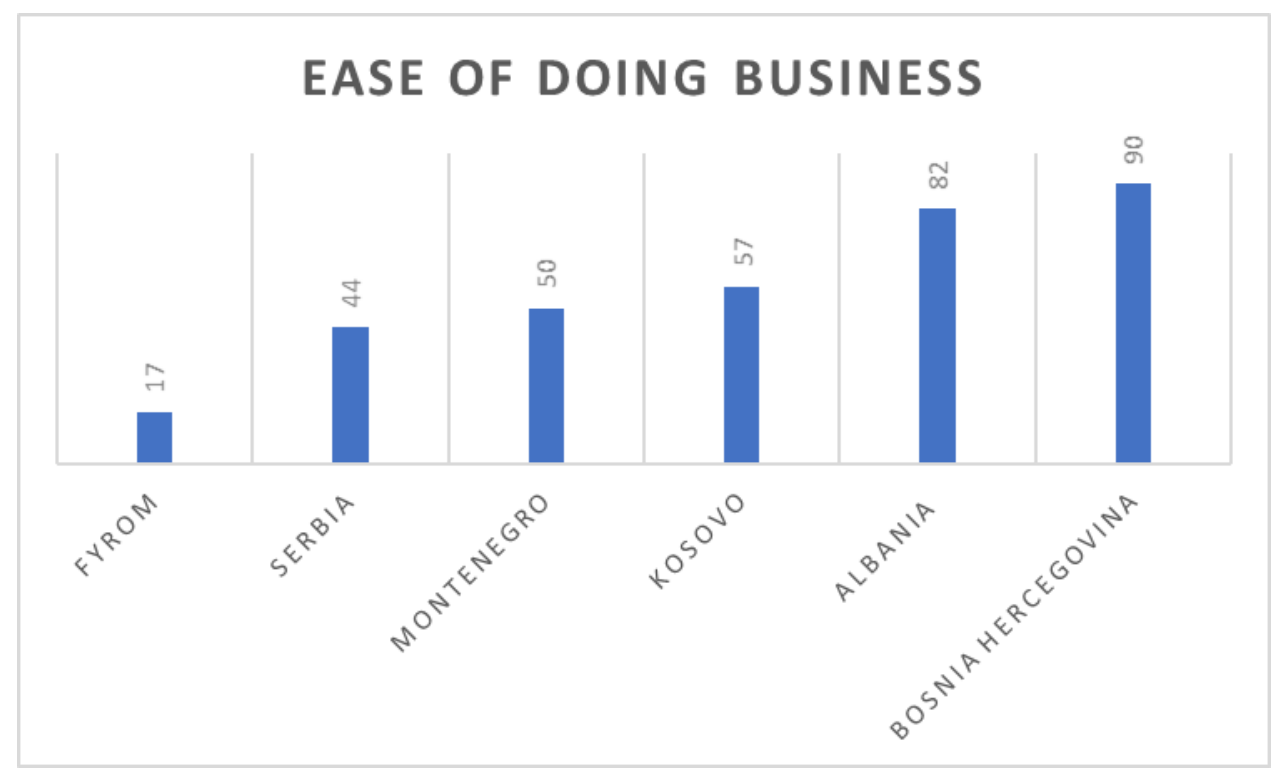

Source: Doing Business, 2020

As it can be seen from the figure above, FYROM has a visible higher ranking than other countries of the Western Balkan's region. Serbia has a good ranking at $44^{\text {th }}$ place among 190 countries. Kosovo and Montenegro have an approximate ranking from 50-57. Albania is classified in the $82^{\text {th }}$ place, while Bosnia and Herzegovina is the last one from the countries involved in this study, ranking in the $90^{\text {th }}$ place.

\section{Conclusions}

At the end of this study we came to the following conclusions:

$>$ The improvement of international trade and the removal of the trade obstacles leads to a higher volume of FDIs.

$>$ High level of corruption is one of the weakest points concerning attraction of FDI in the region of Western Balkans.

$>$ Also political risk and instability in this region remains a very serious problem for FDI-s in the region.

$>$ FYROM is the country with the cheapest tax costs in Balkans, but also represents the highest ranking on ease of doing business compared to other countries studied in this paper. It is focused on the attraction of large investitors in the automobile production sector.

$>$ In the global rankings, FYROM is in $17^{\text {th }}$ place for the ease of doing business meanwhile other countries of the region are ranked from the $44^{\text {th }}$ to the $90^{\text {th }}$ place that is Bosnia and Herzegovina. 


\section{REFERENCES}

1. AIDA (2018). Investime të huaja direkte. Retrieved September 02, 2018, from: http://aida.gov.al/faqe/fdi

2. ALTAX, (2018). Barra Tatimore Në Shqipëri, Kosovë dhe Ballkan, 2018.

3. Gashi P. \& Pugh G. (2015). Marrëdhëniet Tregtare mes Kosovës dhe Bashkimit Evropian - Shikim përtej Marrëveshjes për Stabilizim dhe Asocim. Fondacioni i Kosovës për Shoqëri të Hapur. Retrieved September 04, 2018, from: http://kfos.org/wp-content/uploads/2015/04/Marr\%C3\%ABdh\%C3\%ABniet-Tregtare-mesKosov\%C3\%ABs-dhe-Bashkimit-Evropian_E-KOMPLETUAR.compressed.pdf

4. Imtiaz S. \& Bashir M. F., (2017). Economic freedom and foreign direct investment in South Asian countries. Theoretical and Applied Economics, 2(611), 281-294.

5. Invest in Macedonia (2018). Business Environment. Retrieved September 07, 2018, from: http://www.investinmacedonia.com/investing-in-macedonia/business-environment

6. Kukaj H. \& Ahmeti F. B., PhD, (2016). The Importance Of Foreign Direct Investments On Economic Development In Transitional Countries: A Case Study Of Kosovo. European Scientific Journal, 12 (7), 288 304.

7. MIPA (2017). FDI STATISTICS. Retrieved September 08, 2018, from: http://www.mipa.co.me/en/-fdi-statistics/

8. Palokaj A. \& Tuhina Gj., (2016). Çfarë pas MSA: Raportet Kosovë-BE. Fondacioni i Kosovës për Shoqëri të Hapur. Retrieved September 08, 2018, from: http://kfos.org/wp-content/uploads/2016/11/MSA-shqip_TEXT-2.compressed.pdf

9. Santander Trade Portal (2018). Montenegro: Foreign Investment. Retrieved September 22, 2018, from: https://en.portal.santandertrade.com/establish-overseas/montenegro/investing

10. Santander Trade Portal (2018). Serbia: Foreign Investment. Retrieved September 05, 2018, from: https://en.portal.santandertrade.com/establish-overseas/serbia/investing

11. The World Bank. (2020). Doing Business http://www.doingbusiness.org/en/rankings\#

12. UNCTAD World Investment Report 2020 http://World Investment Report 2020 | UNCTAD 